\title{
Kernos
}

Revue internationale et pluridisciplinaire de religion grecque antique

$27 \mid 2014$

Varia

\section{Gunnel EKROTH, Jenny WALLENSTEN (ed.), Bones \\ Behavious and Belief}

Jan-Mathieu Carbon

(2) OpenEdition

Journals

\section{Electronic version}

URL: http://journals.openedition.org/kernos/2250

DOI: $10.4000 /$ kernos. 2250

ISSN: 2034-7871

\section{Publisher}

Centre international d'étude de la religion grecque antique

\section{Printed version}

Date of publication: 1 November 2014

Number of pages: $480-483$

ISBN: 978-2-87562-055-2

ISSN: 0776-3824

\section{Electronic reference}

Jan-Mathieu Carbon, «Gunnel ekroth, Jenny wallensten (ed.), Bones Behavious and Belief », Kernos [Online], 27 | 2014, Online since 12 November 2014, connection on 22 September 2020. URL : http:// journals.openedition.org/kernos/2250 ; DOI : https://doi.org/10.4000/kernos.2250

This text was automatically generated on 22 September 2020.

Kernos 


\title{
Gunnel EKROTH, Jenny WALLENSTEN (ed.), Bones Behavious and Belief
}

\author{
Jan-Mathieu Carbon
}

\section{REFERENCES}

Gunnel EKROTH \& Jenny WALLENSTEN, Bones, Behaviour and Belief. The Zooarchaeological Evidence as a Source for Ritual Practice in Ancient Greece and beyond, Stockholm, Svenska Institutet I Athen, 2013. 1 vol. $22 \times 27,5$ cm, 275 p. (Acta Instituti Atheniensis Regni Sueciae, series in $\left.4^{\circ}, 55\right)$. ISBN : 978-91-7916-062-3.

1 This alliteratively titled assemblage is both attractive and absorbing. Far from the ossified remains one might dread from old texts, dry excavations, or sterile laboratories, the conference proceedings bring to light a variety of fresh data and new perspectives. We learn about such poorly understood but everyday life events as the extraction of marrow, bones as the chew-toys of dogs and rodents, not to mention the virtually ubiquitous presence of shells and little bits of fish. No one studying Greek sacrifice can now neglect the study of biological remains and all that it entails.

2 Zooarchaeology is a palpably emerging and dynamic field, and yet the bones are not cut and dried. Beyond being extremely informative, nearly all of the papers engage in important methodological, terminological and interpretative issues. For instance, several of the papers rightly stress that ritual deposits can occur in both a sacred and a domestic context, as can food preparation and waste deposits: the line between the sacred and the secular is often blurred or difficult to distinguish. Furthermore, there can sometimes be a disconnect between the textual sources and the practices of deposition which are physically in evidence. A solution, advocated throughout, is the methodical case-by-case study and contextual interpretation of the zooarchaeological finds.

3 The focus of the volume is not disproportionately on the Greek world, which might be taken as both a compliment and a failing. ${ }^{1}$ As the subtitle announces, there is a wealth 
of material from different cultures, from which any reader will benefit a great deal. It helps to think outside of the box, but it also takes us rather far afield from the Mediterranean and its sanctuaries. More critically, however, the research presented seldom reaches a level of stimulating cross-fertilisation or illuminating comparison. In fact, the lack of sustained effort to foster interdisciplinary research may be the volume's single but crucial flaw.

Given the roots of the conference, there is an understandable predilection for Scandinavian and particularly Swedish archaeology. In the brief report of S. Sten, we learn about medieval burials well-appointed with a variety of sacrificial animals. M. Vretemark studies bone deposits in bogs or wells compared to those found in settlements. As mentioned, these papers have the added value of discussing terminology and methods of analysis. O. Magnell gives a nice précis of what a taphonomic investigation should consist in (p. 116-118), and concludes that this study of depositions "serves to reconstruct the chronology of the ritual" (to some degree, at least).

5 Methodological points are also manifest in the survey concerning Iron Age France by A. Gardeisen. The author well illustrates a large variety of practices ranging from "fagot" or bundle-style depositions, inhumations, and wholesale depositions, to burial ("viatique") sacrifices. But the paper also tackles Greek sacrifice in a vague and unhelpful section (p. 46-48, without references in the footnotes). Perhaps the most coherent of these non-Greek papers is the investigation of P. Popkin, focussed on a single sacrifice (a 20 to 24 month-old male sheep) at Kilise Tepe. Building on the work of A. Mouton on Hittite rituals, it admirably advances the process of juxtaposing archaeological material with written sources (texts detailing foundation or purificatory rituals, etc), thus revealing the potential for elucidating both at the same time.

6 In an impressively wide-ranging and learned study which brings us to the Greek world, $K$. Trantalidou looks at a great number of sites and zooarchaeological finds, principally from the Aegean area during the Iron Age. As we would expect, sheep and goats form a sizeable majority of the data, across all zones and periods. Here too there are helpful scientific distinctions brought to the fore, for example the contrast between burial as form of sacrifice in and of itself, and deposition as a method of disposing of the remains of a completed sacrifice. But the paper oscillates between careful (p. 80) and bold interpretations, sometimes hurtling itself against the stumbling blocks of 'behaviour' and 'belief'. Eyebrows are raised when reading, in the case of Akrotiri, that (p. 71): "Le choix des animaux mâles reflète les idées sous-jacentes de la zoo-mythologie universelles; bélier, bouc, taureau comme symboles de fécondité, de prospérité, emblèmes de pouvoir [etc]". While there is often only a short jump between bones and behaviour, there is a precipitous leap from there to 'belief'. Most of the contributions are commendably cautious on the first interpretative step. They are more shaky on the second, though understandably so.

7 Several specifically local or regional case-studies are included, together constituting a strength of the volume and at the same time leading us to somewhat firmer ground. V. Isaakidou and P. Halstead not only present burnt deposits of bones from Mycenaean Pylos, but also offer a good introduction to zooarchaeological method and its utility in the study of ritual behaviour. For instance, it will be compelling (though perhaps not surprising) for those who study later periods to read that it was likely an elite group (20 people or so) which regularly performed a sacrifice of cattle, from which followed a 
widespread distribution of meat, "so that palatial banqueting performed and reaffirmed the social structure and social relationships of the Pylian polity" (p. 93).

D. Mylona gives a synopsis of the incredibly wide variety of remains from a cistern in the sanctuary of Poseidon at Kalaureia, which contains some 13000 elements, especially snakes and seashells, but many other bones and fish as well. In the hope of interpreting the behaviour at play, we are given short and helpful paragraphs with further bibliography on the unusual types of animals represented in the finds, but the result is an impossibly vague set of "common trends and associations" (p. 160-161), whose "broad frame of reference" (save perhaps the sacrifice of equids and fish to Poseidon, p. 157) remains elusive. T. Theodoropoulou studies the edible shells, chiefly cockles, found in the adyton of the Archaic to Hellenistic temple on the Middle Plateau in Kythnos. The paper examines fish sacrifices more generally and contains much useful material, but once again several generalising considerations on Greek sacrifice (p. 205-206), as well as speculation on the possible identity of the recipient (p. 208-211). The broad surveys proposed by Mylona and Theodoropoulou have the appearance of exhaustivity, but actually obfuscate the matters at hand. Both papers suitably conclude on the absence of definite conclusions and the need for further work. The editors, here and in a few other papers, should have sharpened their scissors or taken out their red pens.

H. Brun and M. Leguilloux provide a detailed analysis of the sacrifices which took place in the Sarapieion $C$ on Delos. The vast majority consisted of poultry, which was consecrated as a holocaust, though the animals were probably decapitated before being deposited on the altar fire. There are also small portions of sheep and pigs, especially burned fragments of legs and heads. While the authors plausibly suggest practical reasons for this evidence - altars insufficient in size to burn larger animals completely - and economical ones too, it might also be thought that some larger sacrifices simply took place in a mode like a Greek thysia. Written sources attest to sacrifices of both birds (LSAM 36, lines 9-11, joint cult of Sarapis and Isis at Priene) and other animals, probably livestock, whose legs were extracted for priests of Sarapis as was customary (LSAM 34, lines 10-12, Magnesia-on-the-Meander).

D. Ruscillo provides an account of the finds in the Archaic to late Hellenistic sanctuary of Demeter at Mytilene. Any assessment of rituals for Demeter and Persephone should now take into account this set (and other similar bodies) of zooarchaeological material, though of course much still remains uncertain. There is a particularly good engagement with the substantial sources available for the festival of the Thesmophoria. Calcined bones of piglets have been found in a circular sacrificial pit (i.e. one of the megara), where there is also evidence for the burning of barley and grape seeds, along with other varied remains (again shells, fish, etc). The author notably proposes an intriguing hypothesis about the putrefaction of the piglets during the rites: it may have been rapidly caused through partial digestion by snakes found (infrequently) in the pits.

11 Whereas several contributions are primarily concerned with taxonomy, with M. MacKinnon's study we zoom in on specific osteological details arising from clusters of finds in different contexts at the sanctuary of Zeus in Nemea. There are, for instance, very interesting notes on calcination and what it can tell us about the intensity of fires. Perhaps an even more scientific approach might be possible in the future, helping to further reconstruct this temporal dimension of rituals. The crucial finding is that the 
left thighbones of sheep were usually offered to the hero Opheltes/Archemoros at Nemea, but not the right and not the osphys that was offered to Zeus on his altar. MacKinnon has admirably drawn attention to this significant left or right aspect of bone remains and it will be now be an essential question to raise in future studies. But one may justifiably be skeptical of whether this sagittal distinction reflects an Olympian/Chthonian dichotomy, as the author tentatively claims (p.140-141). MacKinnon is surely right to criticise Lupu (p. 141 with n. 33) who phrases a traditional but overly simplistic separation between divine (left leg) and priestly (right) portions. The point should be that greater nuance is needed. We need not be strictly dualistic about portions: since filleting occurred in some cases and the take-away from a thigh would then be a boneless "gigot mou" (Ekroth citing J.-L. Durand, p. 21 with fig. 8), and since the thighbone could be offered separately (wrapped in the omentum vel sim.) on the altar, both the god and the priest might share a single right or left leg, as the given case might be.

There are a few papers which attempt to build bridges across the specific areas of investigation. G. Forstenpointner, A. Galik, and G.E. Weissengruber's note on experimental archaeology - i.e. recreating sacrificial practices and practical scenarios for the purposes of comparison - is a good but concise case. It points both to the attraction of this method and to its failings, namely circular reasoning. Yet what is striking is that the limits of enquiry are inherently visual. On Greek vases, the tail or curving osphys is immediately recognisable from its unique characteristics (p. 234-236), but undistinguishable bundles -wrapped thighbones? gallbladders? - are by nature a subject for conjecture (p. 237-238).

13 Akin to this danger of "foregone conclusions" is the wider problem which animates most papers in the volume: the difficulty of successfully interpreting the sacred or secular context of assemblages. In an enlightening complement to the issue, two papers by G. Ekroth and by S. Scullion respectively offer valuable perspectives on the question of eating "unsacrificed meat", for example deer and dogs (p.22-25 and 246-253).2 Taken together, they convincingly argue, in Scullion's words, that "the Greeks sacralized selectively rather than universally" (p. 253). Ekroth and Scullion each advance a (too) small series of case-studies where zooarchaeological evidence can be confronted with other sources for Greek sacrifice. Reflecting a theme of the volume, the wider conclusion of Ekroth's paper is that, as far as sacrifice is concerned, "different kinds of evidence speak of different kinds of realities" (p. 26). This is certainly valid to the extent that one needs to be cognisant of the diversity both of the facts and of investigative starting-points. But it would be preferable to reframe the notion in more positive and less relativistic or hyperskeptical terms: as students of Greek religion in a wide sense, it is the varied, but perceptible middle ground of realia which interests us first and foremost.

14 There is a struggle for such unity and coherence in these proceedings, but it is also inherent to the topic at hand. Though the volume brings us closer, we still struggle to grasp how all of the disiecta membra of sacrifices fit together. To take one specific example, several papers comment on the underrepresentation of footbones in assemblages (e.g. Isaakidou and Halstead p. 92; MacKinnon p. 139). The hypothesis proffered is that feet were often left attached to the hide flayed from the animal. That is probable in some cases, but what about the frequent mentions of feet as specific prerogatives in the textual evidence for Greek sacrifice, or the gigot mou depicted with 
the foot attached (cf. above)? As elsewhere in the volume, an effort to confront the osteological findings more closely and carefully with iconographic and textual material might have proven beneficial. In reality, then, constituting a sacrificial "wishlist" would be a much more comprehensive and systematic enterprise.

That being said, it is hard to not to commend and recommend such a book. It is finely produced, abundantly and richly illustrated, and with useful indices. There are lists of sources for each of the individual chapters, but the material is so rich that one would have hoped for a consolidated bibliography. Most importantly, all of the papers exhibit a buoyant commitment to science: a desire for greater precision and caution, and for the gradual accretion of data. The coda by S. Georgoudi, V. Mehl and F. Prost aptly affirms these strengths, and, with good reason, concludes that zooarchaeology substantially modifies many of the "idées reçues" about Greek sacrifice. It is now gradually becoming accepted that even a 'standard' procedure like a thysia could be modified depending on the circumstances. Though there were forms of unity in all of this diversity, there was perhaps no such thing as a 'canonical model' of Greek sacrifice (p. 259-260: indeed, we are encouraged to speak of "des sacrifices grecs" rather than "le sacrifice grec"). This conclusion also underlines the holistic approach necessary for further study. The introduction by the editors (p. 12-13) similarly pleads for continued scholarly collaboration and makes a few innovative proposals: a database of zooarchaeological deposits; additional interdisciplinary conferences. One can only wish the editors success on these praiseworthy endeavours, for which this volume is an excellent first step.

\section{NOTES}

1. In this review LSAM = F. SOKOLOWSKI, Lois sacrées d'Asie Mineure, Paris 1955. Cp. esp. the more geographically focussed volume by Е. котјАвороULоU et al. (eds.), Zooarchaeology in Greece, Recent Advances, Nottingham 2003.

2. Following the earlier work of R.C.T. PARKER, "Eating Unsacrificed Meat", p. 137-145 in: C. CARLIER and C. LEROUGE-COHEN (eds.), Paysage et religion en Grèce antique, Paris 2010. See also now F.S. NAIDEN, Smokes Signals for the Gods, Oxford 2013, Chapter 6 - "Markets and Messes".

\section{AUTHORS}

\section{JAN-MATHIEU CARBON}

Université de Liège 